\title{
Een herstelgerichte benadering van delinquenten met een psychische stoornis ${ }^{*}$
}

\author{
Frans Koenraadt \& Renée Kool
}

Als gevolg van individualisering en het daarmee samenhangend veiligheidsdenken zijn traditionele strafdoelen als resocialisatie en rehabilitatie de afgelopen jaren onder druk komen te staan. ${ }^{1}$ Binnen de sterk verzakelijkte, op efficiëntie gerichte afdoening van strafbare feiten is de ruimte om bij de straftoemeting rekening te houden met de handelingscapaciteiten van de dader verminderd. ${ }^{2}$ Eigen aan de samenleving in het huidige tijdsgewricht zijn bovendien de sterk toegenomen intensiteit en de daarmee samenhangende onzekerheid, vluchtigheid en jachtigheid van het dagelijks bestaan. ${ }^{3}$ Dat roept spanning op ten aanzien van de invulling van langetermijntrajecten als rehabilitatie en resocialisatie, zeker in de forensische geestelijke gezondheidszorg (GGZ). Daar komt bij dat, hoewel Nederland eeuwenlang een reputatie heeft gehad van een tolerant land, de tolerantie voor allerhande deviant gedrag onlangs sterk is afgenomen. ${ }^{4}$ In Nederland tekent zich een allengs strenger strafrechtelijk klimaat af, waarin thans een gere-

* Prof. dr. Frans Koenraadt is hoogleraar Forensische psychologie en psychiatrie aan de Universiteit Utrecht en wetenschappelijk adviseur in het Pieter Baan Centrum (NIFP) te Utrecht en bij de FPK te Assen. Mr. dr. Renée Kool is universitair hoofddocent bij het Willem Pompe Instituut, Universiteit Utrecht.

1 O.a. P.L. Bal, 'Remoralisering van het strafrecht: een discourstheoretische benadering', in: P.L. Bal, E. Prakken \& G.E. Smaers, Veiligheid of Vergelding?, Deventer: Kluwer 2003, p. 3-33; Y. Buruma, 'De explosieve groei van de gevangenispopulatie', in: Y. Buruma \& P.C. Vegter (red.), Terugkeer naar de samenleving (liber amicorum Jan Fiselier), Deventer: Kluwer 2005, p. 49-64; M. Boone, 'Schurende mensbeelden', in: F. de Jong \& R.S.B. Kool (red.), Relaties van gezag en verantwoordelijkheid: strafrechtelijke ontwikkelingen, Den Haag: Boom Juridische uitgevers 2012, p. 291-307.

2 J.W. Fokkens, 'Enkele gedachten over straftoemeting, richtlijnen en resocialisatie', in: Y. Buruma \& P.C. Vegter (red.), Terugkeer naar de samenleving (liber amicorum Jan Fiselier), Deventer: Kluwer 2005, p. 77-85; C. Kelk, 'Forensisch psychiatrisch toezicht in het licht van onze human strafrechtelijke traditie', in: J. van Vliet, A. Andreas \& B. Keuning (red.), Verbinden in de keten, Amsterdam: SWP 2011. Zie ook: M.M. van Rosmalen, S.N. Kalidien \& E.N. de Heer-de Lange, Criminaliteits en Rechtshandhaving 2011, Den Haag: Boom Lemma uitgevers 2012, hoofdstuk 7. Sprake is van een duidelijke trend tot afname van het aantal tbs-opleggingen. Dat kan overigens samenhangen met de afnemende bereidheid mee te werken aan een gedragsdeskundig onderzoek.

3 Z. Bauman, Vloeibare tijden. Leven in een eeuw van onzekerheid, Zoetermeer: Klement 2011.

4 C. de Voogd, Geschiedenis van Nederland, Amsterdam: Arena 2000; G. van den Brink, Mondiger of moeilijker? Een studie naar de politieke habitus van hedendaagse burgers, Den Haag: Sdu 2002. 
duceerd en statistisch vijandbeeld als mensbeeld van de gedetineerde opgeld doet $^{5}$ en waarin penitentiaire instellingen en hulpverleningsorganisaties bureaucratisch zijn gemodelleerd. Waar de GGZ steeds meer is geprofessionaliseerd, is de bedrijfsmatige benadering ook in de forensische sector diep doorgedrongen. De voorwaardenscheppende rol van financiers, subsidieverstrekkers en verzekeraars geeft mede de contouren aan waarbinnen de hulpverlening in de (forensische) GGZ geschiedt. Zij die als dader met de strafrechtspleging te maken krijgen en zij die als patiënt in de (forensische) GGZ verzeild raken, ondervinden allen in meer of mindere mate enigerlei vorm van afwijzing, afkeuring en uitstoting, ${ }^{6}$ met alle nadelige gevolgen van dien.

Niettemin zijn er ook 'zachte krachten' aan het werk. Zo is er zowel binnen de reguliere strafrechtelijke context als die van de forensische GGZ sprake van een groeiende belangstelling voor een herstelgerichte benadering. Deze denkrichting, die inmiddels al weer enkele decennia van zich laat horen, heeft tot nu toe in ons land weinig voet aan de strafrechtelijke grond gekregen. Niettemin lijkt men zich binnen de strafrechtspleging op beleidsniveau bewust te worden van de potentie van herstelrecht. ${ }^{7}$ Maar ook in de verder van het juridische terrein gelegen psychiatrie is de gedachte aan herstel als middel tot rehabilitatie en re-integratie van patiënten met een psychische stoornis in het afgelopen decennium doorgedrongen. ${ }^{8}$ Tegen de stroom van het sociaalbiologische model in, ${ }^{9}$ wordt gepleit voor behandelmethoden waarin herstel vanuit een volwaardige( $r$ ) participatie van de patiënt aan diens behandeling tot uitgangspunt wordt genomen. De achterliggende gedachte is dat 'herstel' niet kan volgen uit een voorgeschreven behandelingsplan, maar actieve betrokkenheid en deelname vraagt van de patiënt en diens sociale omgeving. ${ }^{10}$

5 A. Mooij, Prudentie en evidentie (afscheidsrede Universiteit Utrecht), Den Haag: Boom Juridische uitgevers 2009. In de tweede helft van de twintigste eeuw heeft zich in het strafrecht al een kentering in het mensbeeld voorgedaan, namelijk van dat van 'het in de versukkeling geraakte broertje' dat de helpende hand behoeft naar dat van de mondige rechtsburger, wiens positie op vele fronten moest worden gejuridiseerd, ongeacht of het om de verdachte, de veroordeelde, de gevangene, de ter beschikking gestelde of de justitiabele gaat.

6 J. Boumans \& J. van Weeghel, A literature review on stigma research in the Netherlands, Utrecht: Kenniscentrum Phrenos 2010.

7 A. van Hoek, G.J. Slump \& M. Leijten, De toekomst van herstelrecht in Nederland: bouwstenen voor een toekomstvisie, Amsterdam: Stichting Restorative Justice Nederland 2011; A. van Hoek, G.J. Slump \& M. Leijten, Inventarisatie herstelrechtelijke projecten en activiteiten in Nederland vanaf 1980 tot heden en buitenlandse voorbeelden, Amsterdam: Stichting Restorative Justice Nederland 2011. Voorts: Ministerie van Veiligheid en Justitie 2013.

8 J. van Weeghel, Verlangen naar volwaardig burgerschap; maar wat doen we in de tussentijd? (oratie Universiteit van Tilburg), Tilburg: Universiteit van Tilburg 2010.

9 Kort gezegd wordt door aanhangers van het sociaalbiologisch model betoogd dat geen sprake zou zijn van vrije; het menselijk handelen zou volledig worden gedetermineerd door de individuele 'breincapaciteiten'. Er is kortom sprake van een sterk deterministische visie op het menselijk handelen. Te dezen: V. Lamme, De vrije wil bestaat niet. Over wie er echt de baas is in het brein, Amsterdam: Bert Bakker 2010; D. Swaab, Wij zijn ons brein, Amsterdam: Uitgeverij Contact 2010; T. Prakken, 'Het strafrecht en de kwebbeldoos', in: F. Koenraadt \& R. Wolleswinkel (red.), Homo ludens en humaan strafrech, Den Haag: Boom Lemma uitgevers 2011, p. 51-62.

10 J. van der Stel, Focus op persoonlijk herstel bij psychische problemen, Den Haag: Boom Lemma uitgevers 2012. 
Hoewel onduidelijk is tot welke toepassingen deze ontwakende belangstelling voor het herstelrecht zal leiden, geven deze ontwikkelingen ons aanleiding de vraag te stellen of beide sporen verenigbaar zijn wanneer het gaat om hen die vanwege een ten tijde van het delict bestaande psychische stoornis in rechte niet volledig verantwoordelijk zijn gehouden, maar die omwille van het risicovolle karakter van hun handelen wel op grond van een strafrechtelijke titel worden behandeld en gedetineerd. In deze bijdrage hebben we ons ten doel gesteld deze vraag te verkennen; een volledig antwoord op de vraag naar het potentieel van deze interventiemethoden voor de rehabilitatie van daders met een psychische stoornis wordt niet beoogd.

Daartoe zetten we eerst beide sporen, herstelrecht binnen het domein van het strafrecht respectievelijk herstel als behandelingsmethode binnen het domein van de psychiatrie, uiteen. Aan de hand daarvan zoeken we naar overeenkomsten die een verbinding tussen beide discoursen kunnen bevorderen. Maar ook de mogelijke risico's van zo'n verbinding vermelden we. Zo hopen we een antwoord te vinden op de vraag hoe op verantwoorde(r) wijze vorm kan worden gegeven aan de 'bestraffende behandeling' van daders met een psychische stoornis.

\section{Herstelrecht en actieve verantwoordelijkheid}

Verbindend element in deze bijdrage is het appèl op actieve verantwoordelijkheid bij de dader, dat spreekt uit een herstelbenadering. Herstelrecht is, in al zijn uiteenlopende vormen, erop gericht de bij het 'conflict' betrokken partijen te laten participeren in de afdoening daarvan. ${ }^{11}$ Het past in het concept van 'actief burgerschap' dat sinds enkele jaren opgeld doet en is terug te vinden in justitiële beleidsdocumenten. ${ }^{12}$ Kernwaarden van herstelrecht zijn participatie, herstel (zowel in materieel opzicht als op belevingsniveau) en het centraal stellen van de emoties, ervaringen en behoeften van de direct betrokkenen. Gewerkt wordt vanuit een bottom-up gerichte systeembenadering, waarbinnen horizontale, (inter)menselijke relaties het kader vormen om daders ter verantwoording te roepen. Uitgangspunt is dat dader en slachtoffer in beginsel gelijkwaardig zijn: de dader wordt als volwaardig burger aangesproken op diens verantwoordelijkheid voor de gevolgen van zijn handelen. Hoewel de aanleiding is gelegen in het verleden (het delict), is herstel toekomstgericht: doel van de herstelrechtelijke interventie is te komen tot een herstel van de (gemeenschaps)betrekkingen. ${ }^{13}$

11 Vgl. H. Zehr, The Little Book of Restorative Justice, Intercourse, PA: Good Books 2002, p. 7: 'Restorative Justice is a process to involve, to the extent possible, those who have a stake in a specific offense and to collectively identify and address harms, needs, and obligations, in order to heal and put things as right as possible.'

12 Raad voor Maatschappelijke Ontwikkeling, Aansprekend burgerschap, Den Haag: Sdu 2000, p. 13; E. Claes, 'Punitieve rechtshandhaving, herstelrecht en menselijke gelijkwaardigheid', in: B. van Stokkom (red.), Straf en herstel. Ethische reflecties over sanctiedoeleinden, Den Haag: Boom Juridische uitgevers 2004, p. 229-253; L. Walgrave, Restorative Justice, Self-Interest and Responsible Citizenship, Cullumpton: Willan 2008; Van Hoek, Slump \& Leijten 2011 (De toekomst); 2011 (Inventarisatie). 
Hoewel de 'ontdekking' van de herstelbenadering in de huidige beleidsvisie primair - zo niet volledig - berust op de wens tegemoet te komen aan de wensen van slachtoffers, ${ }^{14}$ is deze eenzijdige focus beslist niet kenmerkend voor het herstelrechtelijk denken. Integendeel, binnen het herstelrecht geldt een 'holistisch' perspectief: dader, slachtoffer en al naar gelang daartoe aanleiding is de omringende gemeenschap, staan centraal. ${ }^{15}$ Daarbij gaat het niet om 'de samenleving', met het daaraan verbonden publiek belang bij herstel van de rechtsorde, maar om de directe leefomgeving van betrokkenen, de groep die terugkeer voor de dader zou kunnen faciliteren. ${ }^{16}$ Daarmee vertoont het hersteldiscours duidelijke gelijkenis met de what works-benadering, ofwel het desistance-discours. Ook daar ligt het vertrekpunt in de (potentiële) agency van betrokkene, zij het wat meer dan in het herstelrecht op de agency van de dader. ${ }^{17}$ Vanuit het vertrekpunt van agency, ofwel: de handelingscapactiteit van de dader, wordt in beide benaderingen toegewerkt naar het vinden van werkzame procedures, gericht op het rehabiliteren van de daders, en - wat betreft het herstelrecht - redress voor het slachtoffer. ${ }^{18}$

Dat laatste aspect, en de wat zwaardere nadruk op het procedurele element, markeert de herstelbenadering. Binnen de herstelbenadering vormt de procedure een essentieel element; alleen dan kan de gewenste uitkomst worden gegenereerd. Claes omschrijft deze procedurele stijl als te zijn gericht op 'narratieve identiteitsvorming' ${ }^{19}$ Alle betrokkenen nemen actief deel aan het communicatieproces en onderhandelen over de voorwaarden waaronder herstel en daaruit voortvloeiende terugkeer voor de dader mogelijk zijn. ${ }^{20}$ Dat kan, zowel van de zijde van de dader als van die van het slachtoffer, alleen op voorwaarde van vrijwilligheid. Herstel kan uit zijn aard nimmer worden afgedwongen, maar vormt de uitkomst van een 'bemiddeling' tussen dader en slachtoffer, met op de achtergrond de leefgemeen-

Ministerie van Veiligheid en Justitie 2013, par. 3.2.2.

15 Voor een uiteenzetting van de kenmerken van herstelrecht, alsmede een inventarisatie van initiatieven in (o.a.) Nederland: Van Hoek, Slump \& Leijten 2011 (De toekomst), 2011 (Inventarisatie).

16 Vgl. Raad voor Maatschappelijke Ontwikkeling 2000, p. 13: ‘(...) verantwoordelijkheid speelt zich (...) af binnen een web van sociale relaties, waarin mensen elkaar ter verantwoording roepen en aan elkaar verantwoording afleggen. Het is dat web van sociale relaties - de context - dat een evenwichtige combinatie van zelfredzaamheid en betrokkenheid mogelijk maakt.'

17 F. McNeill, 'What works in probation', PROCES 2009/3, p. 129-146.

18 Over de betekenis van dergelijke rehabilitatierituelen: M.M. Boone, 'Rehabilitatierituelen', in: J.P. van der Leun, E.R. Muller, N. van der Schee, P.M. Schuyt \& M.A.H. van der Woude (red.), De vogel vrij ((liber amicorum Martin Moerings), Den Haag: Boom Lemma uitgevers 2011, p. 255-267.

19 Claes 2004, p. 238-239.

20 J. Deklerck \& A. Depuydt, 'Straf, herstel en verbondenheid. Van individualiserende naar personerende verantwoordelijkheid', in: B. van Stokkom (red.), Straf en herstel. Ethische reflecties over sanctiedoeleinden, Den Haag, Boom Juridische uitgevers 2004, p. 211-229. 
schap waartoe zij behoren. ${ }^{21}$ Het ter verantwoording roepen van de dader is prospectief gericht: via het bewerkstelligen van herstel voor het slachtoffer wordt de dader als persoon ter verantwoording gesteld en in staat gesteld te re-integreren. Voor de klassieke strafprocedure ligt dat anders; daarin wordt eveneens weliswaar geappelleerd aan de verantwoordelijkheid van de verdachte/dader, maar deze wordt niet actief bij het ontwerp van de afdoening en de procedure betrokken. Het strafrecht markeert de verantwoordelijkheden, maar draagt niet wezenlijk bij aan de vorming van de daarmee geduide morele en sociale verantwoordelijkheden. ${ }^{22}$

$\mathrm{Nu}$ is het aanbrengen van een verbinding tussen het herstelrecht en het strafrecht niet onomstreden. Integendeel, de opvatting dat de inbedding van het herstelrecht niet geheel onttrokken kan worden aan de publiekrechtelijke context zou volgens sommigen afbreuk doen aan de horizontale benaderingswijze van het herstelrecht. De noodzaak tot het waarborgen en daardoor sterk gereglementeerde karakter van een strafrechtelijke afdoening zou, zo luidt het bezwaar, afbreuk doen aan de communicatie die vereist is om te komen tot het gewenste resultaat: het tot elkaar brengen van dader, slachtoffer en gemeenschap. ${ }^{23}$ Zo'n gewaarborgde procedurele inkadering is, wanneer het gaat om afdoening van strafbare feiten, echter onontkoombaar. Juist dan immers is sprake van (maatschappelijke) behoefte aan een 'rituele afdoening'. ${ }^{24}$ De kunst is om binnen de gegunde procedurele ruimte te komen tot het maximale resultaat: een geslaagde bemiddeling. De praktijk laat zien dat ook dan goede resultaten kunnen worden geboekt. ${ }^{25}$

Terugleidend naar de hier besproken kwestie van de resocialisatie van de dader, moet echter ook worden gewezen op de risico's die liggen besloten in een herstelbenadering, namelijk die van een te eenzijdige gerichtheid op het slachtoffer en een daaruit volgende objectivering van de dader. $\mathrm{Nu}$ is dat risico niet beperkt tot de herstelbenadering, maar eigen aan alle vormen van 'responsief recht'. Omdat er binnen de huidige, op dienstbaarheid van het slachtofferbelang gerichte

21 Overigens moet de stelling dat herstel niet kan worden afgedwongen, worden gerelativeerd. Zo is Walgrave van mening dat herstel ook kan worden opgelegd. Deze positie moet echter worden begrepen in samenhang met zijn categorale afwijzing van het straffen als opzettelijke leedtoevoeging. Het gedwongen opleggen van herstel is dan acceptabel vanuit de opvatting dat het slachtoffer het 'recht' heeft te worden hersteld in de rechtmatige toestand. Dat laatste impliceert een 'functionele' reactie, en niet een die bestaat uit intentionele leedtoevoeging; Walgrave 2009. Vanuit een desistance-benadering lijkt zo'n opgelegd herstel echter spanning op te roepen en resocialisatie in de weg te staan. De daarvoor vereiste handelingscapaciteiten bij de dader worden immers - gelet op de gebruikte dwang - niet 'spontaan' geactiveerd.

22 C. Kelk, 'Individuele verantwoordelijkheid en herstel', in: B. van Stokkom (red.), Straf en herstel. Ethische reflecties over sanctiedoeleinden, Den Haag: Boom Juridische uitgevers 2004, p. 257-273, i.h.b. p. 261.

23 P. McCold, 'Toward a Mid-range Theory of Restorative Criminal Justice: A Reply to the Maximalist Model', Contemporary Justice Review 2000, 3, p. 357-414.

24 A. Duff, Punishment, Communication and Community, Oxford: Oxford University Press 2001; R.S.B. Kool, 'Herstel: een communicatieve vorm van wraak', Tijdschrift voor Herstelrecht 2005, 3, p. 24-34.

25 I. Vanfraechem, I. Aertsen \& J. Willemsen, Restorative Justice Realities. Empirical Research in a European Context, Den Haag: Eleven International Publishing 2010. 
beleidsfocus een voorkeur lijkt te bestaan voor responsief recht en daarin ons inziens reële belemmeringen liggen besloten voor de resocialisatie van daders, gaan we hier kort op in.

Onder de noemer responsief recht gaat namelijk een amalgaam aan opvattingen schuil, waarbinnen het recht wordt gezien als een instrument ter verwezenlijking van maatschappelijke doeleinden die alle zijn gericht op het bewerkstelligen van 'rechtvaardigheid' en het creëren van een morele gemeenschap. Onder die ogenschijnlijk 'zachtaardige' noemer kunnen echter 'harde krachten' schuilgaan, in het bijzonder wanneer sprake is van een therapeutisch gestuurde rechtstoepassing. ${ }^{26}$ Eerder heeft Daems erop gewezen dat het herstelrecht gevaar loopt onderwerp te worden van zo'n therapeutisering. ${ }^{27}$ Hoewel sommigen deze waarschuwing onterecht vinden, ${ }^{28}$ menen wij dat deze gelet op de huidige beleidsfocus op zijn minst serieus genomen moet worden. ${ }^{29}$ Wat men ook vindt van de immer toenemende aandacht voor het slachtoffer, duidelijk is dat dit zich kan keren tégen de dader en kan leiden tot verenging van de focus op retrospectieve verantwoordelijkheid. Daarmee zouden mogelijkheden tot een prospectiever afdoening geblokkeerd kunnen raken en dreigt de in oorsprong responsief ingestelde herstelrechtelijke benadering te verworden tot instrument van repressie. ${ }^{30}$

Het vorenstaande geeft slechts een grove schets van de mogelijkheden die liggen besloten in het herstelrecht. Niettemin hopen we te hebben laten zien dat het daarin gelegen appèl op actieve verantwoordelijkheid de sanctionering van daders (inclusief eventuele insluiting) op een zinvoller wijze kan bevorderen dan het geval is bij een traditionele strafrechtelijke afdoening. Daarbij is het, zoals opgemerkt, zaak ons bewust te zijn van daarin besloten risico's van omgekeerde effec-

26 S. Verberk, Probleemoplossend strafrecht en het ideaal van responsieve rechtspraak, Den Haag: Sdu 2011.

27 T. Daems, 'Een sluimerende therapeutisering?', Tijdschrift voor Herstelrecht 2007, 1, p. 7-22.

28 A. Pemberton, 'Sluimerende therapeutisering van herstelrecht?', Tijdschrift voor Herstelrecht 2007, 3, p. 19-32.

29 Kool 2012. Overigens blijkt uit de studie van Verberk naar de in de Verenigde Staten gepraktiseerde vormen van responsief recht, in het bijzonder de onderscheiden vormen van 'therapeutic jurisprudence', geen sprake te zijn van een overwaardering van het slachtofferbelang. Integendeel. Zij constateert dat alleen in geval van 'domestic violence courts' sprake is van slachtofferparticipatie, met daaruit voortvloeiende versterking van de punitiviteit (Verberk 2011, p. 35).

30 B. Fellegi, "Explaining the impact of restorative justice. The "4-way interaction" of morality, neutralisation, shame and bonds', in: R. Mackay, M. Bosnjak \& J. Deklerck (red.), Images of Restorative Justice Theory, Frankfurt am Main: Verlag für Polizeiwissenschaft 2008, p. 205-224. Eveneens Verberk, die betoogt dat responsief recht kan omslaan in repressief recht wanneer de rechtspraak zich verbindt met politiek. Juist door de ogenschijnlijk integere rechterlijke wens om via samenwerking met 'zorgautoriteiten' te komen tot zinvolle oplossingen kan immers een controlerend maar gelijktijdig ook punitief netwerk ontstaan. Het is hier niet de plaats om hierover uit te wijden, maar juist in het door publiek vertrouwen in de staat gekenmerkte Nederlandse strafrechtssysteem zou zo'n 'samensmelting' van krachten kunnen plaatsvinden. Zo'n benadering wordt geschetst in het advies van de RMO betreffende de afstemming van 'straf en zorg'; RMO, Straf en zorg: een paar apart, Amsterdam: SWP 2007 (zie ook Moerings 2011). Anderzijds vergt dat een zekere bereidheid tot samenwerking en het slechten van institutionele muren. Daarvan heeft men binnen het door Verberk beschreven Amerikaanse systeem minder last; de individuele handelingsruimte van de strafrechter lijkt daar groter. Verberk (2011, p. 279) spreekt derhalve van 'collaborative justice'. 
ten. Daarop komen we later nog terug. Eerst stellen we ons de vraag hoe de hiervoor beschreven mogelijkheden kunnen worden toegepast op daders die als gevolg van belemmeringen in hun psychische vermogens op eigen wijze moeten worden aangesproken. Dat die ruimte bestaat, blijkt uit de in het navolgende te bespreken actuele inzichten binnen de (forensische) psychiatrie.

\section{Herstel in de geestelijke gezondheidszorg}

Bij ernstige psychische problemen kent herstel in de GGZ vier typen. Klinisch herstel is van oudsher een centrale vorm waarbij onder begeleiding door hulpverleners, met door hen geïnitieerde interventies, een als wenselijk opgevatte toestand wordt nagestreefd. Bij functioneel herstel gaat het om het bevorderen dat (ex-)patiënten een nieuwe start maken met het inrichten van hun leven, zoals met opleiding, werk, huisvesting enzovoort; kortom, hier staat de rehabilitatie centraal. Maatschappelijk herstel beoogt de inspanningen tot integratie in de samenleving met allerhande belangengroepen. Bij het persoonlijk herstel gaat het om het maatwerk en wel om het perspectief van de individuele persoon, waarin de vraag aan de orde is wat de invloed van de psychische problematiek is geweest op de identiteit en het gevoel van eigenwaarde van de persoon. ${ }^{31}$

Herstel impliceert het herstellen van een ziekte en is een eigen, anders dan gebruikelijk in de GGZ, stijl waarmee men met een psychische stoornis omgaat. Daarbij wordt een appèl gedaan op de eigen kracht en mogelijkheden van de patient bij het hervinden van de regie en bij het inhoud geven aan het eigen leven. ${ }^{32}$ Niet de beperkingen staan centraal, maar de wel beschikbare vaardigheden, competenties en/of mogelijkheden. Herstelgericht werken sluit aan op het dagelijks leven van de patiënt en maakt gebruik van de vaardigheden die de patiënt wél bezit, en is daarbij gericht op wonen, werken en dagbesteding, leren, sociale contacten. Om deze doelen te bewerkstelligen wordt vooral een ambulante aanpak bevorderd, wordt hospitalisatie zo veel mogelijk tegengegaan en wordt samengewerkt in de wijk. Dat brengt met zich mee dat de hulpverleners 'outreachend' zijn, en dat in klinisch verband een beddenreductie wordt aangemoedigd. Daarbij bestaat voor de hulpverlening een gedeelde verantwoordelijkheid met gemeenten. ${ }^{33}$

Uitgangspunt voor het menselijk handelen blijft onveranderd dat de mens van oudsher individueel verantwoordelijk is voor zijn gedrag. Dit vertrekpunt geldt zowel binnen het strafrecht als binnen de psychiatrie en betreft verantwoordelijkheid jegens zichzelf, jegens anderen en jegens het gezag van de overheid. De patient staat in de (forensische) GGZ niet als object, maar als subject (met eigen wil, emoties, streven en beleving) centraal in de begeleiding en behandeling. In een samenleving waarin het mensbeeld zich heeft ontwikkeld tot dat van te beheer-

31 Van der Stel 2012, p. 43-45.

32 Aldus E. van der Haar, bestuurder GGZ Drenthe, bij de presentatie van Samen werken aan herstel en welbevinden, Assen, 11 oktober 2011.

33 E.A.H.M. Linders, De betekenis van nabijheid. Een onderzoek naar informele zorg in een volksbuurt, Tilburg: Universiteit van Tilburg 2010. 
sen en te controleren burger, waarin van ieder mens fragmenten worden geregistreerd die weer met elkaar kunnen worden verbonden, ligt dan bij uitstek voor de hulpverlening een taak om hierin integratie (van genoemde fragmenten) aan te brengen - in samenspraak met de patiënt. ${ }^{34}$ Ook Dröes betoogt dat herstelprocessen in de GGZ drie dimensies kennen: herstel van gezondheid, herstel van maatschappelijk functioneren en herstel van de persoonlijke identiteit. ${ }^{35}$ Tussen deze drie velden liggen vloeiende verbindingen; dit samenspel leidt ertoe dat herstel in de GGZ is verbonden met empowerment en resocialisatie. Vooralsnog zien we de herstelpraktijken vooral ten behoeve van de chronische patiënten functioneren, met als doel een volwaardig burgerschap te (doen) verwerven voor en door deze groep. ${ }^{36}$ Ervaringsdeskundigheid en cliëntenparticipatie staan daarbij hoog in het vaandel. Herstelgerichte zorg gaat uit van de eigen kracht van mensen die in staat zijn gezonde keuzes te maken en die verantwoordelijkheid voor hun eigen gedrag kunnen en willen nemen. Terwijl in de gehele GGZ herstelgerichte zorg wordt bepleit, wordt deze in de forensische GGZ wel beoogd, maar toch nog expliciet buiten beeld gelaten. ${ }^{37}$

\section{Herstel in de forensische geestelijke gezondheidszorg}

Evenals de reguliere GGZ, omarmt de forensische GGZ, zij het schoorvoetend, de herstelbenadering. Daarbij wordt gebruikgemaakt van de principes van de inmiddels vaak toegepaste forensische werkwijze assertive community treatment (ACT), die zijn toegesneden op de specifieke behoeften van de forensische psychiatrische doelgroep: ${ }^{38}$

1 de zorg dient in de gemeenschap plaats te vinden;

2 de hulpverleners werken in een mobiel team, met huisbezoeken of afspraken op de plaats waar de patiënt verblijft;

3 de zorg is permanent, in weekeinden en avonden toegankelijk;

4 het team is in staat intensieve zorg te bieden; en

5 deze (intensieve) zorg is afgestemd op de cultuurspecifieke kenmerken en problemen van patiënten.

34 F. Koenraadt, De centrale positie van grensgevallen. Hun tijd, plaats en persoon in de forensische psychologie (oratie Universiteit Utrecht), Den Haag: Boom Juridische uitgevers 2008.

35 J. Dröes, Nieuwe namen voor een oude dame (lezing Schizofreniecongres 19 november 2009), Utrecht: Kenniscentrum Phrenos 2009.

36 Van Weeghel 2010; J. van Weeghel \& I. Borgers, 'Mensen met ernstige psychische aandoeningen: beeldvorming, zelfbeeld en burgerschap', in: A. van Kalmthout, T. Kooijmans \& H. Moors (red), Mensbeeld, beeldvorming en mensenrechten, Nijmegen: Wolf Legal Publishers 2011, p. 57-73.

37 Het visiedocument van GGZ Nederland zegt daarover dat het niet specifiek ingaat 'op de forensische zorg. Dit neemt echter niet weg dat uitgangspunten uit de visie ook voor cliënten uit deze groepen van toepassing zijn. Zij maken immers deel uit van de totale doelgroep waar het visiedocument zich op richt'; GGZ Nederland, Naar herstel en gelijkwaardig burgerschap. Visie op de (langdurende) zorg aan mensen met ernstige psychische aandoeningen, Amersfoort: GGZ Nederland 2009, p. 7.

38 C. Place, M. van Vugt, H. Kroon \& L. Neijmeijer, Modelbeschrijving forensische (F)ACT. Richtlijnen voor de werkwijze en het zorgaanbod van forensische ACT- en FACT-teams, Utrecht: Trimbos Instituut 2011, p. 14. 
Herstel van de patiënt geldt binnen deze behandelmethode als centraal doel. Vanwege de specifieke, forensische kleuring van de problematiek nemen individueel risicomanagement en rehabilitatieplannen een belangrijke plaats in binnen de geboden zorg. ${ }^{39}$ Patiënten in de forensische GGZ zijn vaak verstoken van hun thuis, van hun werk, van hun roots, soms ook van zichzelf. Zij zijn verbrokkeld geraakt, waarbij de samenleving voor hen vluchtiger is geworden dan deze al was. Patiënten kunnen niet - althans slecht, zo blijkt veelvuldig - met hun tijd omgaan, met als gevolg: verveling, frustratie en wellicht terugval en recidive. Voor veel patiënten in de forensische GGZ vallen verleden, heden en toekomst samen. ${ }^{40}$ In de op herstel gerichte begeleiding en behandeling is men met de patient op zoek om permanentie, duurzaamheid, hechting, verbondenheid in het bestaan aan te brengen. ${ }^{41}$ Herstel betekent gelegenheid jezelf te hernemen. Het tijdsperspectief is steeds meer gaan ontbreken, waardoor het aanbod van een dagprogramma met werk en activiteiten van 9 tot 5 essentieel is, mede ter voorbereiding op terugkeer in de samenleving. In de organisatie van het zorgaanbod moet die continuïteit van integrale zorg verankerd zijn, ${ }^{42}$ namelijk in een flexibele overgang van klinische naar ambulante zorg, ingebed in een wijdvertakte ketenzorg. Op deze herstelgerichte wijze wordt vanuit de forensische GGZ getracht een volwaardig burgerschap te bewerkstelligen voor mensen die niet alleen te kampen hebben met ernstige psychische aandoeningen, maar ook met het strafrecht in aanraking zijn gekomen. Die laatste kwalificatie drukt een zeker stempel op het te realiseren herstel: veelal is immers sprake van een bepaalde mate van gevaar dat moet worden verdisconteerd in de behandelmethode. De rol van de forensisch psychiatrische patiënt is niet een passieve, maar een actieve: hij verleent in het herstelproces betekenis aan zijn psychische problematiek en daarmee aan het delinquente gedrag, en trekt daaruit lering. Hier geldt dat deze, door een dubbele

39 Zie voor een nadere toepassing van herstel in de samenwerking tussen de dr. H. van der Hoevenkliniek en de Stichting Beschermende Woonvormen Utrecht (SWBU): M.D. Posthouwer \& J.L.D.J. Berndsen, 'Terugkeer naar de maatschappij vraagt om maatwerk', in: H. Groen, M. Drost \& H. Nijman (red.), Handboek forensische geestelijke gezondheidszorg, Utrecht: De Tijdstroom 2012, p. 371-383.

40 Uit haar aard kent de forensische GGZ een specifieke gerichtheid in tijd: retrospectief, actueel en prospectief. Zo is ook het forensisch gedragskundig rapport een document in de tijd: een verslag van bevindingen en verantwoording van onderzoek naar de onderzochte op het moment of in de periode van onderzoek, verslag van bevindingen van retrospectief onderzoek naar de onderzochte op het moment of in de episode van het ten laste gelegde, en verslag van prospectief onderzoek naar de gevaarlijkheid of risico's van onderzochte in de (nabije) toekomst. In vervolg op de forensisch gedragskundige rapportage doet zich een soortgelijke oriëntatie in de tijd ook voor in de behandeling.

41 Zoals de werkwijze, verankerd in de visie van de Divisie Forensische Psychiatrie (DFP) van GGZ Drenthe te Assen.

42 Die nadrukkelijke samenhang tussen klinische en ambulante begeleiding en behandeling, waarmee continuïteit c.q. permanentie wordt beoogd, is van meet af aan uitgangspunt van de aanpak van de DFP Assen: geen kliniek zonder polikliniek. 
'identiteit' gekenmerkte groep, individuen als persoon niet samenvallen met hun ziekte, noch met het door hen gepleegde delict. ${ }^{43}$

Hier past tevens vermelding van de contacten tussen dader en slachtoffer die in de behandelingsfilosofie van enkele forensische c.q. tbs-klinieken gestalte krijgen, zowel in de klinische als in de ambulante behandeling. Zulke confrontaties zijn vaak zinvol, zowel voor het slachtoffer of de nabestaanden als voor de dader. Deze gesprekken kunnen het slachtoffer helpen bij het verwerkingsproces, als deze kan uitspreken welke gevolgen een delict op zijn leven heeft gehad. Daarnaast kan het slachtoffer tijdens een confrontatie vaak zijn beeldvorming bijstellen. Een confrontatie kan voor de dader onderdeel zijn van de behandeling; hij leert verantwoordelijkheid te dragen en krijgt inzicht in de gevolgen van zijn daad. Dergelijke confrontaties tussen dader en slachtoffer zijn alleen mogelijk als de dader in staat is verantwoordelijkheid te nemen voor zijn daden. ${ }^{44}$ Van Weeghel betoogt over dat proces van resocialisatie en rehabilitatie: 'Bescheidenheid over wat we kunnen, en erkenning van wat we niet kunnen bereiken, is een belangrijke waarde (naast de waarden verantwoordelijkheid en solidariteit) in de rehabilitatiepraktijk. ${ }^{45}$

\section{Tot slot}

Wat leert het vorenstaande over het potentieel van op herstelgerichte interventiemethoden voor de rehabilitatie van daders met een psychische stoornis? Als gezegd, beogen we slechts een verkenning daarvan te geven, een sluitend antwoord blijven we (vooralsnog) schuldig. Niettemin menen we duidelijk te hebben gemaakt dat de herstelbenadering voor de resocialisatie van geestelijk gestoorde gedetineerden beloften in zich draagt. Weliswaar heeft het herstel in het strafrecht een andere ontwikkeling doorgemaakt en een andere invulling gekregen dan het herstel in de (forensische) GGZ, maar in beide sectoren is sprake van een voorzichtige kentering in de richting van het initiëren van relationele processen, waarin de individuele verantwoordelijkheid van de betrokkene (dader, patiënt) een centrale rol vervult, zowel retrospectief als prospectief. In beide sectoren ook is de herstelbenadering voorzien als een alternatief, maar is het uiteindelijk veeleer als een extra, of wellicht beter: persoonsgerichte(r), interventie gaan fungeren.

Het is duidelijk dat er verschillen bestaan tussen beide 'sferen'. Waar binnen de forensische psychiatrie de aandacht klassiek vanzelfsprekend gericht wordt op de persoon van de patiënt/delinquent, is dat niet het geval in het reguliere domein van de strafrechtelijk georiënteerde herstelpraktijk. Integendeel, daar ligt de nadruk op de noodzaak van herstel voor het slachtoffer en de gemeenschap. Het

43 O.R.J. Delleman, Naar een integrale psychiatrie. De psychiater als specialist van gemankeerde zingeving, en de patiënt als vormgever van het herstelproces, Utrecht: Universiteit voor Humanistiek 2008, p. 126.

44 Aldus informatie van de zijde van 'De Forensische Zorgspecialisten', voorheen de dr. H. van der Hoevenkliniek te Utrecht.

45 Van Weeghel 2010, p. 17. 
instrumentaliseren van de verantwoordelijkheid en het appèl daartoe op de dader is, althans in de mainstream van de herstelrechtelijke strafpraktijken - ondanks de oorspronkelijke intentie van het herstelrecht -, slechts in tweede instantie gericht op diens re-integratie.

Dit gegeven zal eveneens gelden voor de psychisch gestoorde delinquent. De huidige gerichtheid op maatschappelijke veiligheid werkt dit in de hand. Daarnaast moet ervoor worden gewaakt deze gevaarsdimensie, verbonden aan de status van delinquent, te verabsoluteren. Ook de patiënt in de geestelijke gezondheidszorg zou, strikt genomen, vanuit zijn ziekte een bepaald maatschappelijk gevaar kunnen vertegenwoordigen. Echter, het gegeven dat de delinquent, al dan niet onder invloed van een psychische stoornis, blijk heeft gegeven van maatschappelijk gevaarzettend gedrag betekent niet dat dit zijn eindstation zou moeten zijn. Integendeel, volwaardig burgerschap betekent dat eenieder op schending van de daarin gelegen afspraken naar eigen capaciteiten mag en moet worden aangesproken, maar impliceert niet dat daarmee alle 'rechten' om deel uit te mogen maken van de gemeenschap zijn verspeeld. Het is dat uitgangspunt dat is te herkennen in de binnen het strafrecht en de (forensische) psychiatrie en psychologie voorgestane herstelbenadering.

Het is volgens ons de moeite waard de in deze benadering gelegen mogelijkheden tot herstel van menselijke betrekkingen nader te verkennen en uit te bouwen. Daarbij geldt wel de waarschuwing dat men niet al te hoge verwachtingen moet koesteren. Herstelgerichte toepassingen vergen inspanningen van betrokkenen, en het slagen ervan zal (mede) afhankelijk zijn van de competenties waarover men beschikt. Dat gegeven geldt zowel voor het slachtoffer als voor de dader, maar in het bijzonder voor de psychisch gestoorde delinquent. Voor hem vormt het ziektebeeld immers nog steeds een extra ballast, zo niet een dubbele handicap. Wil een appèl op zelfregie en zelfactivering als besloten liggende in een herstelgerichte benadering slagen, dan zal rekening moeten worden gehouden met de aanwezigheid van specifieke competenties bij betrokkenen en zullen de procedures hierop zo nodig dienen te worden aangepast. ${ }^{46}$ Meer nog dan het geval is bij de klassieke wijze van afhandeling van delicten respectievelijk behandeling van psychische stoornissen, is maatwerk vereist. 